\title{
Angiotensin II receptor subtypes and cardiac function
}

\author{
M. DE Gasparo*, H. RogG*, M. Brink $\dagger$, L. Wang $\ddagger$, S. Whitebread*, G. Bullock $\ddagger$ and P. ERne§
}

*Cardiovascular Research Department, Pharmaceuticals Division, CIBA-GEIGY Limited, Basel, †Morphology Group, Pharmaceuticals Division, Ciba-Geigy Lid, Basel, $\ddagger$ Department of Research, University Hospital Basel, §Division of Cardiology, Kantonsspital, Lucerne, Switzerland

KEY WORDS: $\mathrm{AT}_{1}$ receptor subtype, $\mathrm{AT}_{2}$ receptor subtype, human heart, heart failure.

All the components of the renin-angiotensin system have been identified in the heart including the angiotensin II receptor subtypes $A T_{1}$ and $A T_{2}$.

In the normal human heart, there is a decreasing receptor density from the right atrium to the left ventricle. In right atrial membranes prepared from pathological hearts, the percentage of $A T_{1}$ receptor decreases with the severity of cardiac dysfunction whereas that of $A T_{2}$ receptor increases. Treatment of hypertrophic rats with $A T_{1}$ receptor antagonists inhibits cardiac hypertrophy and reverses the increase receptor density, indicating involvement of this Ang II receptor subtype. The role of the $A T_{2}$ receptor is still largely unknown but it may be involved in cell growth and proliferation. The cloning of both $A T_{1}$ and $A T_{2}$ receptors as well as the availability of potent and selective antagonists will help us to understand better the functional role of Angiotensin II in cardiovascular disorders.

\section{Introduction}

It was previously thought that the renin-angiotensin system (RAS) was a purely endocrine system acting entirely through the peptide hormone angiotensin II (Ang II) in the blood. During the past decade, the existence of a tissue RAS has become more firmly established ${ }^{[1]}$. Angiotensinogen renin, angiotensin converting enzyme (ACE) and Ang II have all been demonstrated in various tissues including the heart ${ }^{[2-4]}$. Use of molecular biology has proven beyond doubt the extra-renal expression of the RAS specific messenger RNAs (mRNA) and therefore the local synthesis of the members of the cascade, thereby excluding sequestration from the circulation ${ }^{[3,6]}$. Generation of the biologically active peptides can also be induced in isolated perfused hearts, indicating that it is independent of the plasma RAS ${ }^{[7]}$. Both cultured neonatal rat cardiomyocytes and ventricular fibroblasts have been shown to express angiotensinogen and renin mRNA as well as ACE and are able to synthesize Ang I [ ${ }^{[8.9]}$.

The existence and functional significance of Ang II receptors in the heart have also been demonstrated ${ }^{[0-12]}$. When radioactive Ang II is injected into the left ventricle of adult rats, it localizes preferentially around the nucleus of cardiac muscle cells, suggesting the existence of Ang II nuclear binding sites ${ }^{[13]}$. More recently, Ang II binding sites have been observed in purified liver nucle ${ }^{[14,15]}$ and have been shown to modulate the transcription of mRNA for renin and angiotensinogen, suggesting a role of Ang II in intracellular regulation of the RAS ${ }^{[16]}$.

These findings therefore clearly indicate that there is intra-cardiac synthesis of RAS components, and clinical

Correspondence. M. de Gasparo, Cardiovascular Research Department, Pharmaceuticals Division. K 125-1015, Ciba-Geigy Lid, 4002 Basel, Switzerland. evidence for an active RAS in the heart has been obtained from the effective use of ACE inhibitors in the treatment of congestive heart failure, heart hypertrophy, coronary atherosclerosis, myocardial infarction and post-infarction remodelling ${ }^{\mid 3,6,17-19]}$.

The purpose of this short review is to summarize the present knowledge on the Ang II receptor in the heart and to discuss the potential role of the Ang II receptor subtypes in the pathophysiology of heart diseases.

\section{Location and characterization of Ang II receptors in the heart: animal studies}

The first radioligand binding report using Ang II and 19-day old chick embryo cardiocytes was made by Moore in $1980^{[20]}$. Since then, Ang II binding sites have been identified in rabbit, guinea-pig, bovine, chicken, rat, pig, monkey and human heart ${ }^{211}$. In the early studies, one or two binding sites with high and low affinity were reported and guanine nucleotides modulated their affinity, suggesting a coupling with a G-protein ${ }^{[10]}$. It is only recently that two different receptor subtypes, called $\mathrm{AT}_{1}$ and $\mathrm{AT}_{2}$ have been described using selective ligands ${ }^{\{2,23\}}$. Losartan (DuP 753) binds specifically to the $\mathrm{AT}_{1}$ receptor, whereas CGP 42112 and $\mathrm{PD} 123177$ have a high affinity for the $\mathrm{AT}_{2}$ receptor. $A T_{1}$ and $\mathrm{AT}_{2}$ are essentially distinguished by two other characteristics: firstly, sensitivity to reducing agents like dithiothreitol (DTT) which decrease binding of Ang II by the $\mathrm{AT}_{1}$ receptor, whereas binding by the $\mathrm{AT}_{2}$ receptor is increased $^{[24]}$. Secondly, in contrast to the $A T_{1}$ subtype, GTPYS has been shown to have no effect on the $A_{2}$ binding characteristics, thus indicating a lack of coupling of this receptor to a $\mathrm{G}$ protein ${ }^{[2]}$.

Using the same criteria, two receptor subsets were identified in rabbit ventricular membrane ${ }^{[26]}$. The $\mathrm{AT}_{1}$ subtype 
has a $\mathrm{Kd}$ of $31 \mathrm{nM}$ for losartan, whereas the $\mathrm{AT}_{2}$ subtype shows a Kd of $0.5 \mathrm{nM}$ for CGP 42112. The two receptor populations have an almost identical affinity for Ang II (1.5 and $1.2 \mathrm{nM}$ for the $\mathrm{AT}_{1}$ and $\mathrm{AT}_{2}$, respectively) and the ratio of $\mathrm{AT}_{1} / \mathrm{AT}_{2}$ is nearly equal (60:40). Chang and Lotti confirmed this ratio in the rabbit heart and also that of the monkey ${ }^{[27]}$. In an undefined strain of rat, however, these authors reported a high proportion of $\mathrm{AT}_{1}$ receptor subtype $(90 \%)$, suggesting an heterogeneity amongst species ${ }^{[28]}$. In contrast, equal proportions of $\mathrm{AT}_{1}$ and $\mathrm{AT}_{2}$ were seen in 'in situ' binding assay on tissue sections obtained from fetal, neonatal and adult Sprague Dawley rats $^{[29]}$. Interestingly, the density of the receptor was at least twice as high in the neonatal as in the adult heart, indicating that the receptor expression is developmentally regulated. Myocytes, freshly isolated from neonatal rats through a Percoll column, express roughly $20 \%$ of the $\mathrm{AT}_{2}$ receptor subtype. The $\mathrm{AT}_{2}$ receptors, however, seem to disappear rapidly during primary culture (Rogg, Ramjoué and Whitebread, unpublished observation). This observation is important in the interpretation of results obtained from such culture preparations for detection and quantitation of Ang II receptors subtypes.

As in other tissues ${ }^{[24]}$, the $\mathrm{AT}_{1}$ and $\mathrm{AT}_{2}$ receptor subtypes in the heart can be characterized by their different sensitivities to disulfide reducing agents, the binding of the $\mathrm{AT}_{2}$ receptor being increased and that of $A T_{1}$ decreased after DTT treatment ${ }^{[26]}$.

\section{Cellular location in the heart}

It is known that the heart is a heterogeneous tissue and cardiomyocytes occupy nearly $76 \%$ of the structural space, but represent only one third of all cells ${ }^{[30]}$. The remaining cells $(2 / 3)$ are made up from fibroblasts, endothelial cells, vascular smooth muscle cells, macrophages, nerve cells, and specialized cells of the conduction system. Membrane binding assays cannot determine whether the $\mathrm{AT}_{1}$ and $\mathrm{AT}_{2}$ receptor are co-expressed in the same cells, or if the two receptor subtypes are expressed in different cells. Knowledge of where and via which receptors Ang II exerts its cardiac action could give important clues as to the function of the receptor subtypes. Early studies have shown low density binding in the myocardium, moderate to high density binding throughout the conduction system, and high density binding in the autonomic nervous system ${ }^{[31-33]}$. Iwami et al. ${ }^{[3+]}$ separated cardiomyocytes and nonmyocytes from neonatal rat heart and evaluated the $\mathrm{AT}_{1}$ mRNA levels in these fractions. Interestingly, the $A T_{1}$ receptor mRNA was primarily located in non-cardiomyocyte fractions in adult rat heart ${ }^{[34]}$. We have performed in vitro binding to localize Ang II receptors at the light microscopic level on sections of rabbit heart using film or emulsion autoradiography for detection. As illustrated in Fig. 1, a high density of Ang II receptors was detected in nerve cells next to intramural coronary arteries. Subtype-selective agents have been used in competition with radiola-
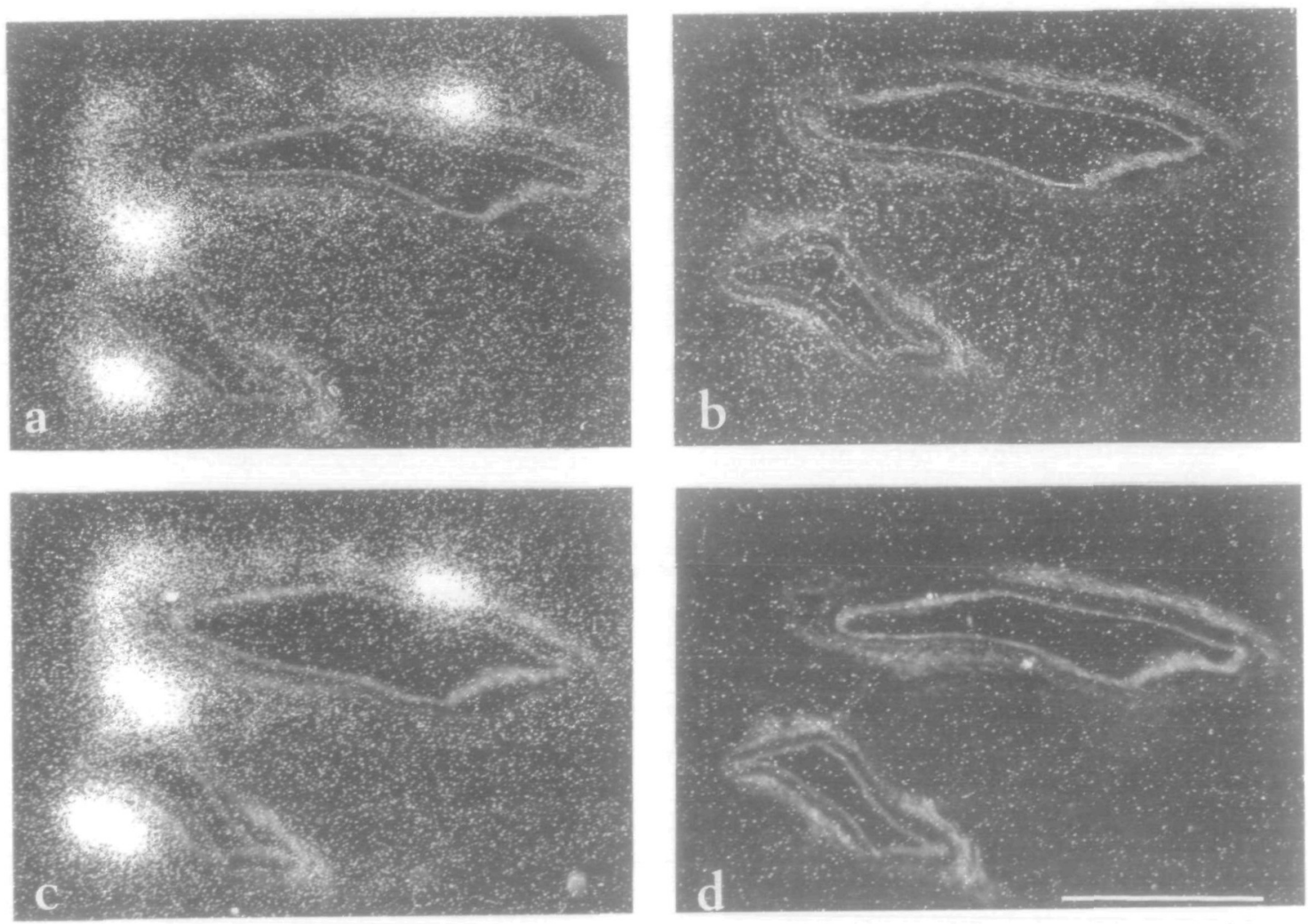

Figure I Dark-field micrographs showing the location of Ang II receptor subtypes in rabbit heart parasympathetic nerve cells situated next to intramural coronary arteries. Adjacent sections were incubated with $0.25 \mathrm{~nm}^{125} \mathrm{I}_{-}\left[\mathrm{Sar}^{1}\right.$, II $\left.\mathrm{e}^{\mathrm{k}}\right]$ Ang II in the absence (a), or presence of $1 \mu \mathrm{M}$ Ang II (b), $100 \mathrm{nM}$ CGP42112 (c) or $1 \mu \mathrm{M}$ losartan (d). Binding was visualized using the coverslip emulsion autoradiograhy method ${ }^{[65]}$. All Ang II receptors are of the AT, subtype. (bar $\left.=100 \mu \mathrm{m}\right)$. 
belled $\left[\mathrm{Sar}^{1}, \mathrm{IIe}^{8}\right]$ Ang II to determine the receptor subtype expressed in the parasympathetic nerves. The binding was totally inhibited by the $\mathrm{AT}_{1}$ antagonist losartan and not by the $\mathrm{AT}_{2}$ competitor CGP42112, indicating that the nerve cells contain only the $\mathrm{AT}_{1}$ receptor subtype. Subtyping has also been performed in the conduction system of the rat heart. Saavedra et al. ${ }^{[35]}$ detected only the $\mathrm{AT}_{1}$ receptor subtype in both sinoatrial (SA) and atrioventricular (AV) nodes, whereas Sechi et al. found the same ratio of $A T_{1}$ to $\mathrm{AT}_{2}$ in cardiac tissue and in the myocardium of the rat with a greater density of the receptor in AV rather than in SA nodes $^{[29]}$.

\section{Ang II receptors in the human heart}

Binding studies have also been performed in human cardiac tissue and the presence of both the receptor subtypes observed in rat and rabbit heart has been confirmed ${ }^{[36]}$.

Atria, right and left ventricles from five normal people not eligible as heart donors and right atrial tissues from 35 patients undergoing heart surgery, were investigated. In normal heart tissue, the density of the receptor (mean SEM) decreased from the right atrium $(323 \pm 35 \mathrm{fmol} / \mathrm{mg}$ protein; $\mathbf{n}=5)$ to the left ventricle $(118 \pm 30 ; n \pm 5)$. The amount of Ang II receptor measured in this study is significantly higher than that which was reported earlier for human heart by Urata $e t$ al. ${ }^{[32]}$. The difference may be due to the tissue collection procedure and the preparation of the membrane. The two different subtypes can be distinguished, the $\mathrm{AT}_{1}$ receptor accounting for $60 \%$ in both chambers. In right atrial membranes from pathological hearts, Ang II receptors (mean $\pm \mathrm{SEM} ; \mathrm{n}=35$ ) were present in high density ( $406 \pm 60 \mathrm{fmol} / \mathrm{mg}$ protein) and affinity (1.4 $\pm 0.18 \mathrm{nM}$ ). The two different subtypes (Fig. 2) were also detected with a relative abundance of $A T_{1}$ receptor, of $33 \pm 2 \%$ (mean $\pm S E M ; n=35)$. These results indicate a considerable change in the $\mathrm{AT}_{1} / \mathrm{AT}_{2}$ ratio between normal and diseased hearts ${ }^{[3]}$.

\section{The Ang II receptors and cardiac function}

There is no doubt as to the implications of Ang II in postinfarction remodelling, in cardiac hypertrophy and in heart failure. However, the Ang II receptor subtypes involved remains to be established.

The potential relationship of the Ang II receptor subtypes to parameters of cardiac function was investigated in the right atria of 35 patients undergoing coronary bypass surgery and/or valve replacement. The left ventricular ejection fraction was measured before, and right and left atrial pressure were recorded during surgery. There was no correlation between any of the measured cardiac functions and total Ang II receptor density or affinity. However, the percentage of $\mathrm{AT}_{1}$ receptors was significantly higher in the atria of patients with normal right atrial pressure $(\mathrm{r}=0.901 ; P<0.001)$ and left ventricular ejection fraction ( $\mathrm{r}=0.74 ; P<0.001)$ while the percentage of the $\mathrm{AT}_{2}$ receptor was positively correlated with the levels of left atrial pressure $(r=0.853 ; P<0.001)$. Hence, the ratio of $\mathrm{AT}_{1}$ and $\mathrm{AT}_{2}$ receptors in atria shows a good correlation with right atrial and left ventricular function ${ }^{[39]}$. Also, with

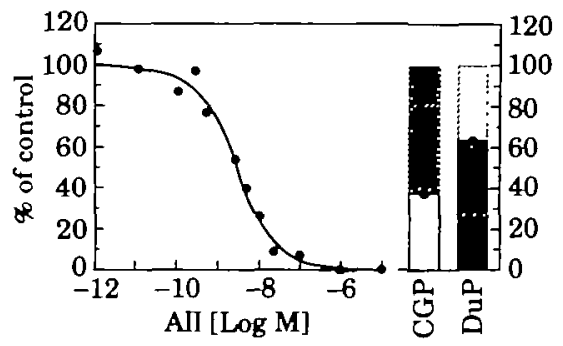

Figure 2 Inhibition of ${ }^{125} \mathrm{I}$-Ang II binding to membranes of human atria and quantitation of the receptor subtypes. The radioligand and varying amounts of unlabelled Ang II or subtype selective ligands were incubated with the membrane fraction $(5 \mu \mathrm{g}$ of protein), and the receptor binding studies were performed and quantitated as described ${ }^{[26]}$. The solid circles represent the values obtained from the tissue of one patient determined in duplicate. The total receptor density was $405 \pm 60 \mathrm{fmol}^{-1} \mathrm{mg}$ protein (mean $\pm \mathrm{SEM} ; \mathrm{n}=35$ ) and the $\mathrm{Kd}$ value for Ang II was $1.4 \mathrm{nM}$. The proportions of Ang II receptor subtypes were determined in competition binding experiments by their sensitivity to subtype selective concentrations of losartan (formerly named DuP 753; selective for the $\mathrm{AT}_{1}$ subtype) and CGP 42112 (selective for $\mathrm{AT}_{2}$ ). The CGP column represents the data obtained in the presence of CGP 42112 $(0.3 \mu \mathrm{M})$. The white area, the resistant section, represents the $\mathrm{AT}_{1}$ receptors and the hatched area the sensitive section represents the $\mathrm{AT}_{2}$ receptors. DuP shows the inverse experiment using losartan $(3 \mu \mathrm{m})$ where the resistant section represents the $\mathrm{AT}_{2}$ receptors (hatched area) and the sensitive section the $\mathrm{AT}_{1}$ receptors (white area). The mean of these two cross-experiments was used to calculate the $\mathrm{AT}_{1} / \mathrm{AT}_{2}$ ratio $(33 \pm 2 / 66 \pm 2$; mean $\mathrm{SEM} ; \mathrm{n}=35)$. In the patient represented in this Fig. the ratio was $37 / 63$.

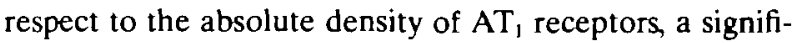
cant difference was found in atrial tissue from patients with normal vs pathological left ventricular function (Fig. 3). Similarly, the relative abundance (mean \pm SEM) of $A T_{1}$ receptor was lower in left ventricles of heart from cardiac transplant recipients $(40 \pm 4 ; n=9)$ compared with normal hearts which were not used for transplantation $(60 \pm 4$; $n=5$ ), suggesting a selective down-regulation of the $\mathrm{AT}_{1}$ receptor in these patients. From these data the proposal

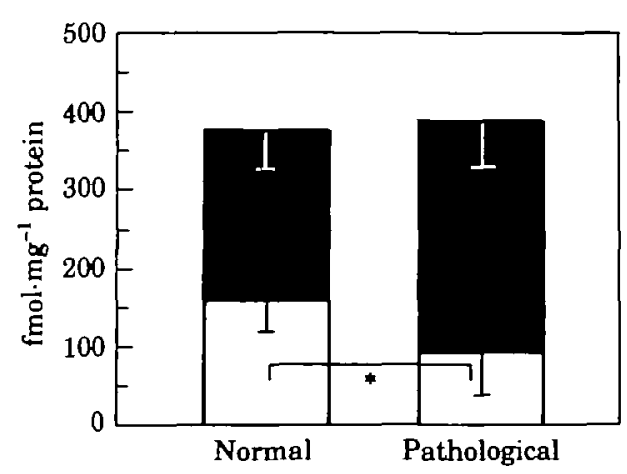

Figure 3 The proportion of $\mathrm{AT}_{1}(\square)$ and $\mathrm{AT}_{2}(\square)$ receptors in atrial membranes of patients with normal ejection fraction (EF $>60 \% ; n=8)$ and pathological left ventricular function ( $E F<49 \% ; n=16$ ). The asterix indicates a significant difference $(\mathrm{P}<0-05)$ in the $\mathrm{AT}_{1}$ receptor density $\left(\mathrm{fmol}^{-\mathrm{i}} \cdot \mathrm{mg}\right.$ protein $)$. 
can be put forward that the more severe the heart failure, the lower the $\mathrm{AT}_{1}$ and the higher the $\mathrm{AT}_{2}$ receptor proportion or density[38]. The same observation has been made in rats hearts after aortic banding in which cardiac $\mathrm{AT}_{1}$ receptors are down-regulated in pressure-overloaded left ventricular hypertrophyi39].

Our working hypothesis described above could be challenged in the light of some studies reported in the literature. For example, in contrast to previous observations in human and rat heart, an up-regulation of both $\mathrm{AT}_{1}$ and $\mathrm{AT}_{2}$ receptor expression was reported in rat cardiac hypertrophy ${ }^{[40.41]}$. A threefold increase in ventricular $\mathrm{AT}_{1 \mathrm{~A}}$ mRNA levels, an isoform of the $\mathrm{AT}_{1}$ receptor expressed in vascular tissues ${ }^{[22]}$, and 1.7-fold rise in Ang II receptor densities were observed in spontaneously (SHR) and renovascular hypertensive (WKY) rats ${ }^{\{0,41\}}$. In these studies, the proportion of $\mathrm{AT}_{1}$ and $\mathrm{AT}_{2}$ receptors measured with selective ligands was nearly equal and remained unchanged during the progression of the hypertrophy. Regression completely reversed the increased levels of mRNA and receptor density to the control levels. We cannot yet explain the discrepancy between human and these animal studies but it may be related to the experimental models.

An increased density of the Ang II receptors was also observed in isolated myocytes obtained from rat hearts with myocardial infarction after coronary artery ligation ${ }^{[43]}$. Only the $\mathrm{AT}_{1}$ receptor subtype was detected, but as has been previously stated, the $\mathrm{AT}_{2}$ subtype rapidly disappears during the primary culture (Rogg et al. unpublished data) and so the effect of the culture conditions must be taken into account.

\section{The role of the Ang II receptor in cardiac pathophysiology}

Many reports suggest that the $\mathrm{AT}_{1}$ receptor subtype plays a major role in cardiac pathophysiology. The Ang II receptor antagonist $\mathrm{L} 158809$ administered to rats in drinking water for 7 days after coronary ligation reduced left ventricular systolic and end diastolic pressure as well as the length and diameter of left ventricular myocytes ${ }^{[43]}$. In the same model, early treatment with subcutaneous losartan (15 mg. $\mathrm{kg}^{-1}$. day $^{-1}$ ) only slightly reduced DNA synthesis but, in contrast to captopril, did not affect cardiac output ${ }^{[44]}$. This suggests that the effects of captopril may not be entirely dependent on $\mathrm{AT}_{1}$ receptor-mediated mechanisms. Losartan administered to 3-day-old piglets decreased the left ventricle/body weight ratio and RNA/DNA ratio in the left ventricle, indicating the involvement of the $\mathrm{AT}_{1}$ receptor in the growth of the heart after birth ${ }^{[4,46]}$. Losartan also inhibits the Ang II-induced hypertrophy of cardiac myocytes and hyperplasia of cardiac fibroblasts ${ }^{[47,48]}$. The implication of the $A T_{1}$ receptor in reactive growth processes after myocardial infarction has been documented ${ }^{[49]}$. For example, losartan blocks the induction by Ang II of immediate-early genes ( $c$-fos, $c-m y c$, $c$-jun), late fotal genes ( $\alpha$-actin, ANP receptor genes) and growth factor genes TGF $\beta)^{(50)}$. Finally, the positive inotropic response to Ang II in isolated papillary muscles from rabbit heart ${ }^{[51]}$ or right and left atria from guineapigs $^{[52]}$ were competitively antagonized by losartan. There was no apparent functional consequence of Ang II interaction with the $\mathrm{AT}_{2}$ receptor. Therefore, most, if not all, of the beneficial effects observed with ACE inhibitors on haemodynamic parameters and cardiac hypertrophy will probably be seen after treatment with $\mathrm{AT}_{1}$ receptor antagonists.

The involvement of the $\mathrm{AT}_{2}$ receptor in cardiac pathophysiology remains largely ill defined at the moment. However, Daemen et al. using the model of coronary ligation in the rat have recently described an effect of $\mathrm{AT}_{2}$ receptor blockade ${ }^{[53]}$. After infusion of PD 123319, a specific $\mathrm{AT}_{2}$ antagonist, for 2 weeks by subcutaneous implanted osmotic minipumps at a dose of $3 \mathrm{mg} \cdot \mathrm{kg}^{-1} \cdot \mathrm{day}^{-1}$, the cumulative BrdU labelled fraction in the non-infarcted septum was significantly decreased by $60 \%$. This result suggests that the $\mathrm{AT}_{2}$ receptor subtype is involved in the regulation of DNA synthesis in interstitial cells. The cell-type involved, e.g. fibroblast or endothelial cells, is currently under investigation.

\section{Conclusion}

The importance of the RAS in cardiovascular disease, both experimentally and clinically, has been well illustrated by the beneficial effect observed with ACE inhibitors on inhibiting the development of atherosclerosis, cardiac hypertrophy and remodelling. The Ang II $\mathrm{AT}_{1}$ receptor antagonists discussed here represent a new class of drugs which appear to have the same indications as the ACE inhibitor but possibly a better tolerability profile ${ }^{[54]}$. Their efficacy in human subjects has been proven in hypertension but has still to be demonstrated for other indications.

The existence of two Ang II receptor subtypes in the heart has been demonstrated. As reported previously, blockade of the $\mathrm{AT}_{1}$ receptor alone, in animal and in man, is accompanied by a compensatory increase of circulating Ang II ${ }^{[55-58]}$. This may result in Ang II exerting some hitherto unknown, possibly unwanted effects via the unblocked non- $\mathrm{AT}_{1}$ receptors. The functional importance and clinical relevance of recently identified receptors other than $\mathrm{AT}_{1}$ and $\mathrm{AT}_{2}$, such as $\mathrm{AT}_{3}$ and $\mathrm{AT}_{4}^{[59.60]}$ is not yet known and therefore requires further investigation.

There are some conflicting data in the literature concerning the implication of the $\mathrm{AT}_{2}$ receptor in cardiovascular disease. This leads one to question the validity of the various animal and in vitro models. It appears, however, that there is a 'balance' between the number and distribution of $\mathrm{AT}_{1}$ and $\mathrm{AT}_{2}$ receptors in the human heart suggesting a role for $\mathrm{AT}_{2}$ in the pathophysiology of cardiac dysfunction ${ }^{[61]}$.

Recent advances in the treatment of cardiovascular disorders have paralleled our increase in knowledge about the RAS. With the cloning of both $\mathrm{AT}_{1}$ and $\mathrm{AT}_{2}$ receptors ${ }^{[62-61]}$ and the availability of potent and selective $\mathrm{AT}_{1}$ and $\mathrm{AT}_{2}$ blockers, tools are now available to understand better the biology of Ang II and most probably to open new therapeutic perspectives. 
We are deeply indebted to Dr P. Stultz (Cardiac and Thoracic Surgery, University Hospital, Basel) and to $\mathrm{Dr}$ M. Turina (Cardiac and Vascular Surgery, University Hospital Zurich) for having collected the human heart and without whom our studies would have not been possible. We gratefully acknowledge $A$. Schmid and R. Reut for their excellent technical assistance in the binding studies.

\section{References}

[1] Dzau VJ, Gibbons GH. Autocrine-paracrine mechanisms of vascular myocytes in hypertension. Am J Cardiol 1987; 60: 991-1031.

[2] Dzau VJ, Hirsch AT. Emerging role of the tussue reninangiotensin systems in congestive heart failure. Eur Heart J $1990 ; 11: 65-71$.

[3] Grinstead WC, Young JB. The myocardial renin-angiotensin system: existence, importance and clinical implications. Am Heart J 1992; 123: 1039-45.

[4] Dzau VJ. Local expression and pathophysiological role of renin-angiotensin in the blood vessels and heart. Bas Res Cardiol 1993; 88: 1-14.

[5] Lindpaintner K, Ganten D. The cardiac renin-angiotensin system: a synopsis of current experimental and clinical data. News Physiol Sci 1991; 6: 227-32.

[6] Lee YA, Lindpaintner $K$. The cardiac renin-angiotensin system. From basic research to clinical relevance. Arzneim Forsch/Drud Res 1993; 43: 201-6.

[7] Lindpaintner $K$, Jin $\mathbf{M}$, Wilkeim MJ, Suzuki W, Lynz W, Schoelkens BA, Ganten D. Intracardiac generation of angiotensin and its physiologic role. Circulation 1988; 77 : I-18-I-23.

[8] Dostal DE, Rothblum KN, Chernin MI, Cooper GR, Baker $\mathrm{KM}$. Intracardiac detection of angiotensinogen and renin - a localized renin-angiotensin system in neonatal rat heart. Am J Physiol 1992; 263: C838-50.

[9] Dostal DE, Rothblum KN, Conrad KM, Cooper GR, Baker KM. Detection of angiotensin I and II in cultured rat cardiac myocytes and fibroblasts. Am J Physiol 1992; 263: C851-63.

[10] Baker KM, Campanile CP, Trachte GJ, Peach MJ. Identification and characterization of the rabbit angiotensin II myocardial receptor. Circ Res 1984; 54: 286-93.

[11] Rogers TB, Gaa ST, Allen IS. Identification and characterization of functional angiotensin II receptors on cultured heart myocytes. J Pharmacol Exp Ther 1986; 236: 438-44.

[12] Mukherjee A, Kulkarni PV, Haghani Z, Sutko JL. Identification and characterization of angiotensin II receptors in cardiac sarcolemma. Biochem Biophys Res Commun 1982; 105: 575-81.

[13] Robertson AL, Khairallah PA. Angiotensin II: rapid localization in nuclei of smooth and cardiac muscle. Science 1971; 172: 1138-9.

[14] Booz GW, Conrad KM, Hess AL, Singer HA, Baker KM. Angiotensin-II-binding sites on hepatocyte nuclei. Endocrinology 1992; 130: 3641-9.

[15] Tang SS, Rogg H, Schumacher R, Dzau VJ. Characterization of nuclear angiotensin-II-binding sites in rat liver and comparison with plasma membrane receptors Endocrinology 1992; $131: 374-80$.

[16] Eggena P, Zhu JH, Clegg K, Barrett JD. Nuclear angiotensin receptors induce transcription of renin and angiotensinogen mRNA. Hypertension 1993; 22: 496-501.

[17] Lindpaintner K, Ganten D. The cardiac renin-angiotensin system. An appraisal of present experimental and clinical evidence. Circ Res 1991; 68: 905-21.

[18] Lindpaintner K, Neidermaier N, Drexler H, Ganten D. Left ventricular remodelling after myocardial infaretion - Does the cardiac renin angiotensin system play a role. J Cardiovasc Pharmacol 1992; 20: S41-7.

[19] Dostal DE, Baker KM. Evidence for a role of an intracardiac renin angiotensin system in normal and failing hearts. Trend Cardiovasc Med 1993; 3: 67-74.
[20] Moore A. Development of angiotensin receptors (Vol 130). In: Johnson JA, Anderson RR, eds Advances in Experimental Medicine and Biology. New York: Plenum Press, 1980, 195-8.

[21] Baker KM, Booz GW, Dostal DE. Cardiac actions of angiotensin II: Role of an intracardiac renin-angiotensin system. Annu Rev Physiol 1992; 54: 227-41.

[22] Bumpus FM, Catt KJ, Chiu AT et al. Nomenclature for angiotensin receptors: a report of the nomenclature committee of the council for high blood pressure research. Hypertension 1991; 17: 720-1

[23] Chiu AT, Herblin WF, McCall DE et al. Identification of angiotensin II receptor subtypes. Biochem Biophys Res Commun 1989; 165: 196-203.

[24] Whitebread S, Mele M, Kamber B, de Gasparo $M$. Preliminary biochemical characterization of two angiotensin II receptor subtypes. Biochem Biophys Res Commun 1989; 163: 284-91.

[25] Bottari SP, Taylor V, King IN, Bogdal Y, Whitebread S, de Gasparo $M$. Angiotensin II $\mathrm{AT}_{2}$ receptors do not interact with guanine nucleotide binding proteins. Eur J Pharmacol 1991; 207: 157-63.

[26] Rogg H, Schmid A, de Gasparo M. Identification and characterization of angiotensin II receptor subtypes in rabbit ventricular myocardium. Biochem Biophys Res Commun 1990; 173: 416-22.

[27] Chang RS, Lotti VJ. Angiotensin receptor subtypes in rat, rabbit and monkey tissues: relative distribution and species dependency. Life Sci 1991; 49: 1485-90.

[28] de Gasparo M, Whitebread S, Bottari SP, Levens NR. Heterogeneity of angiotensin receptor subtypes In: Timmermans PB, Wexler RR, eds. Medicinal Chemistry of the Renin Angiotensin System. Amsterdam: Elsevier, 1994 (in press).

[29] Sechi LA, Griffin CA, Grady EF, Kalinyak JE, Schambelan $M$. Characterization of angiotensin II receptor subtypes in rat heart. Circ Res 1992; 71: 1482-9.

[30] Frank JS, Langer GA. The myocardial interstitium. Its structure and its role in ionic exchange. J Cell Biol 1974; 60: 586-601.

[31] Saito K, Gutkind JS, Saavedra JM. Angotensin II binding sites in the conduction system of rat hearts. Am J Physiol 1987; 253: H1618-22.

[32] Urata H, Healy B, Stewart RW, Bumpus FM, Husain A. Angiotensin II receptors in normal and failing human hearts. J Clin Endocrinol Metab 1989; 69: 54-66.

[33] Allen AM, Yamada H, Mendelsohn FA. In vitro autoradiographic localization of binding to angiotensin receptors in the rat heart. Int J Cardiol 1990; 28: 25-33.

[34] Imami K, Do YS, Hsueh WA. Intracardiac distribution of angiotension II AT, receptors. Hypertension 1993; 22: 419 (Abstr).

[35] Saavedra JM, Viswanathan M, Shigematsu K. Localization of angiotensin $\mathrm{AT}_{2}$ receptors in the rat heart conduction system. Eur J Pharmacol 1993; 235: 301-3.

[36] Wang L, Rogg H, Whitebread S et al. Identification and characterization of angiotensin II receptor subtypes in hearts from normals and heart transplant recipients. J Heart Failure 1993; 1(Suppl): 327(Abstr).

[37] Rogg H, de Gasparo M, Gradel E, Stulz P, Erne P. Identification of Angiotensin II receptor subtypes in human atrial tissue. Eur Heart J 1991; 12: 224 (Abstr).

[38] Wang L, Rogg H, Whitebread S, von Segesser L, Stulz P, Graedel E, Turina M, Eme P. Identification and characterization of angiotensin II receptor subtypes in hearts from animals and heart transplant recipients. J Heart Failure 1993; 1: 327 (Abstr)

[39] Tang SS, Diamant D, Rogg H, Schunkert H, Lorell BH, Ingelfinger JR. Rat hearts contain angiotensin II (Ang II) receptors that are downregulated and differentially expressed during hypertrophy. Hypertension 1992; 20: 418 (Abstr).

[40] Suzuki J, Matsubara H, Urakami M, Inada M. Rat angiotensin-II (type-1A) receptor messenger mRNA regulation and subtype expression in myocardial growth and hypertrophy. Circ Res 1993; 73: 439-47. 
[41] Matsubara H, Suzuki J, Urakami M, Inada M. Rat angiotensin II (type 1A) receptor mRNA regulation and its subtypes expression in the myocardial growth and renovascular hypertensive hypertrophy. Hypertension 1993; 22: 439 (Abstr).

[42] Iwai N, Ingami T. Identification of two subtypes in the rat type I angiotensin $\Pi$ receptor. FEBS Lett 1992; 298: 257-60.

[43] Meggs LG, Coupet J, Huang $H$ er al. Regulation of Angiotensin-II receptors on ventricular myocytes after myocardial infarction in rats. Circ Res 1993; 72: 1149-62.

[44] Smits JF, van Krimpen C, Schoemaker RG, Cleutjens JP, Daemen MJ. Angiotensin II receptor blockade after myocardial infarction in rats: effects on hemodynamics, myocardial DNA synthesis, and interstitial collagen content. J Cardiovasc Pharmacol 1992; 20: 772-8.

[45] Beinlich CJ, White GJ, Baker KM, Morgan HE. Angiotensin II and left ventricular growth in newborn pig heart. J Mol Cell Cardiol 1991; 23: 1031-8.

[46] Beinlich CJ, Morgan HE. Control of growth in neonatal pig hearts. Mol Cell Biochem 1993; 119: 3-9.

[47] Mizuno K, Tani M, Hashimoto S et al. Effects of losartan, a nonpeptide angiotensin II receptor antagonist, on cardiac hypertrophy and the tissue angiotensin II content in spontaneously hypertensive rats. Life Sci 1992; 51: 367-74.

[48] Schorb W, Booz GW, Dostal DE, Conrad KM, Chang KC, Baker KM. Angotensin-II is mitogenic in neonatal rat cardiac fibroblasts. Circ Res 1993; 72: 1245-54.

[49] Reiss K, Capasso JM, Huang H, Meggs LG, Li P, Anversa P. ANG-II Receptors, c-myc, and c-jun in myocytes after myocardial infarction and ventricular failure. Am J Physiol 1993; 264: H760-9.

[50] Sadoshima J, Izumo S. Molecular characterization of angiotensin-II induced hypertrophy of cardiac myocytes and hyperplasia of cardiac fibroblasts - critical role of the AT(1) receptor subtype. Circ Res 1993; 73: 413-23.

[51] Scott AL, Chang RS, Lotti VJ, Siegl PK. Cardiac angiotensin receptors: effects of selective angiotensin II receptor antagonists, DUP 753 and PD 121981, in rabbit heart. J Pharmacol Exp Ther 1992; 261: 931-5.

[52] Feolde E, Vigne P, Frelin C. Angiotensin AT1 receptors mediate a positive inotropic effect of angiotensin II in guinea pig atria. Eur J Pharmacol 1993; 245: 63-6.

[53] Daemen MJAP, Smits JFM. Inhibition of interstitial myocardial DNA systhesis after coronary artery ligation in the rat by the angiotensin subtype 2 receptor antagonist PD 123319. Eur Heart J 1993; 14: 861 (Abstr).

[54] Levens NR, de Gasparo M, Wood JM, Bottari SP. Could the pharmacological differences observed between angiotensinII antagonists and inhibitors of angiotensin converting enzyme be clinically beneficial. Pharmacol Toxicol 1992; 71 . 241-9.
[55] Bunkenburg B, Schnell C, Baum HP, Cumin F, Wood JM. Prolonged angiotensin II antagonism in spontaneously hypertensive rats. Hemodynamic and biochemical consequences. Hypertension 1991; 18: 278-88.

[56] Ohtawa M, Takayama F, Saitoh K, Yoshinaga T, Nakashima M. Pharmacokinetics and biochemical efficacy after single and multiple oral administration of losartan, an orally active nonpeptide angiotensin II receptor antagonist, in humans. BR J Clin Pharmacol 1993; 35: 290-7.

[57] Goldberg MR, Tanaka W, Barchowsky A et al. Effects of losartan on blood pressure, plasma renin activity, and angiotensin II in volunteers. Hypertension 1993; 21: 704-13.

[58] Mizuno K, Tani M, Niimura S et al. A specific angiotensin II receptor antagonist, increases angiotensin I and angiotensin II release from isolated rat hind legs: evidence for locally regulated renin-angiotensin system in vascular tissue. Life Sci 1992; 50: PL209-14.

[59] Chaki S, Inagami T. Identification and characterization of a new binding site for angiotensin II in mouse neuroblastoma neuro-2A cells Biochem Biophys Res Commun 1992; 182: $388-94$.

[60] Hanesworth JM, Sardinia MF, Krebs LT, Hall KL, Harding JW. Elucidation of a specific binding site for angiotensin-II(3-8), antiotensin-IV, in mammalian heart membranes. J Pharmacol Exp Ther 1993; 266: 1036-42.

[61] de Gasparo M, Whitebread S, Levens $N$ et al. Pharmacology of angiotensin II receptor subtypes. In: Saez JM, Brownie AC, Capponi A, Chambaz EM, Mantero F, eds. Cellula'r and molecular biology of the adrenal cortex. (Colloque INSERM, Vol 222). London: Colloque INSERM/John Libbey Eurotext Ltd, 1992: 3-17.

[62] Murphy TJ, Alexander RW, Griendling KK, Runge MS, Bernstein KE. Isolation of a cDNA encoding the vascular type-1 angiotensin II receptor. Nature 1991; 351: 233-6.

[63] Sasaki K, Yamano Y, Bardhan S et al. Cloning and expression of a complementary DNA encoding a bovine adrenal angiotensin II type-1 receptor. Nature 1991; 351: 230-3.

[64] Mukoyama M, Nakajima M, Hornuchi M, Sasamura H, Pratt RE, Dzau VJ. Expression cloning of type-2 angiotensin receptor reveals a unique class of seven-transmembrane receptors. J Biol Chem 1993; 268: 24543-6.

[65] Young WS, Kuhar MJ. A new method for receptor autoradiography: $\left({ }^{3} \mathrm{H}\right)$ opoid receptors in rat brain. Brain Res 1979; 179: 255-70. 